Check for updates

Cite this: RSC Adv., 2018, 8, 23230

\section{Bioactive properties: enhancement of hepatoprotective, antioxidant and DNA damage protective effects of golden grey mullet protein hydrolysates against paracetamol toxicity}

\author{
Intidhar Bkhairia, (D) *a Sabah Dhibi, (D) ${ }^{\text {bc }}$ Rim Nasri, ${ }^{a}$ Abdelfettah Elfeki, ${ }^{\text {b }}$ \\ Najla Hfaiyedh, ${ }^{\text {bc }}$ Ibtissem Ben Amara ${ }^{d}$ and Moncef Nasri ${ }^{a}$
}

\begin{abstract}
This study was undertaken to examine the hepatoprotective, antioxidant, and DNA damage protective effects of protein hydrolysates from Liza aurata, against paracetamol overdose induced liver injury in Wistar rats. L. aurata protein hydrolysates (LAPHs) were mainly constituted by glutamic acid (Glu) and glutamine (Gln) and lysine (Lys). In addition, they contained high amounts of proline (Pro), leucine (Leu) and glycine (Gly). The molecular weight distribution of the hydrolysates was determined by size exclusion chromatography, which analyzed a representative hydrolysate type with a weight range of 3-20 kDa. The hepatoprotective effect of LAPHs against paracetamol liver toxicity was investigated by in vivo assay. Rats received LAPHs daily by gavage, for 45 days. Paracetamol was administrated to rats during the last five days of treatment by intraperitoneal injection. Paracetamol overdose induced marked liver damage in rats was noted by a significant increase in the activities of serum aspartate amino transferase (AST) and alanine amino transferase (ALT), and oxidative stress which was evident from decreased activity of the enzymatic antioxidants (superoxide dismutase (SOD), catalase (CAT), and glutathione peroxidase (GPx)), and level of glutathione (GSH), and increased concentration of lipid peroxidation products (MDA). Furthermore, paracetamol increased the DNA damage with liver histopathological changes. LAPH pretreatment significantly attenuated paracetamol-induced hepatotoxic effects, including oxidative damage, histopathological lesions, and apoptotic changes in the liver tissue. Interestingly, LAPHs restored the activities of antioxidant enzymes and the level of GSH, ameliorated histological and molecular aspects of liver cells. The present data suggest that paracetamol high-dose plays a crucial role in the oxidative damage and genotoxicity of the liver and therefore, some antioxidants such us LAPHs might be safe as hepatoprotectors. Altogether, our studies provide consistent evidence of the beneficial effect of LAPHs on animals treated with a toxic dose of paracetamol and might encourage clinical trials.
\end{abstract}

Received 12th March 2018 Accepted 18th June 2018

DOI: $10.1039 / \mathrm{c} 8 \mathrm{ra02178c}$

rsc.li/rsc-advances of the toxic metabolite $N$-acetyl- $p$-benzoquinoneimine (NAPQI), which extensively depletes hepatocellular glutathione (GSH) along with generation of reactive oxygen species (ROS). ${ }^{2}$ There are an estimated 60000 cases of paracetamol overdose annually, with most cases being intentional suicide gestures. ${ }^{3}$ Nearly 26000 overdose patients are hospitalized each year, and an estimated $1 \%$ develops severe coagulopathy or encephalopathy. The mortality attributed to acetaminophen toxicity is 500 per annum, and at least $20 \%$ of these deaths occur in patients with non-intentional paracetamol overdose. ${ }^{3}$ High dose of paracetamol is well known to be toxic to the liver. ${ }^{4}$ When acetaminophen is used in therapeutic doses, most of the drug is metabolized via glucuronidation and sulfation, a very small amount of acetaminophen is metabolized to NAPQI by the hepatic enzyme cytochrome P450 2E1 (CYP2E1). ${ }^{5}$

The antidote $n$-acetylcysteine (NAC) is highly effective at preventing toxicity, provided it is administered within a few hours of the overdose. Subsequently efficacy declines as the 
interval between the overdose and NAC administration increases. ${ }^{6}$ However, despite its efficacy in reducing mortality due to paracetamol poisoning, intravenous NAC can cause anaphylactoid reactions. ${ }^{7}$ Due to the complexity of preparation of NAC as well as its side effects, mistakes are possible. ${ }^{8}$ However, by reason of the narrow treatment and limited timing of NAC, new therapeutic interventions are necessary to be developed for the treatment of paracetamol toxicity.

In recent years, a great deal of interest has been expressed regarding the productions, characterizations, and applications of protein hydrolysates and food-derived biopeptides due to their numerous beneficial health effects. Peptides with biological activities have shown promise as pharmaceutics with the potential to treat a wide variety of diseases. Indeed, increasing demands for functional foods for health care and disease risk reduction are prevalent throughout the world. ${ }^{9}$ The past decade has also witnessed intense interest in functional foods or dietary photochemical which can influence the pharmacological activity of drugs and their toxicities by modifying metabolism system, including drug-metabolizing enzymes and transporters. ${ }^{\mathbf{1 0}}$

In the pharmaceutical industry, liver, a vital organ in the body responsible for metabolizing and detoxification of substances, ${ }^{\mathbf{1 1}}$ is one of the routinely assessed organs during preclinical safety evaluations. Indeed several biological compounds with antioxidant properties proved effective in protecting the liver against deleterious effects of paracetamol overdose. In addition, protein hydrolysates from fish are considered as reservoirs of structurally diverse bioactive materials with numerous biological effects for human's body affects either directly or indirectly in maintaining good health. ${ }^{\mathbf{1 2}}$ Depending on the composition and the sequence of amino acids, these protein hydrolysates, which contain a complex mixture of peptides, can exhibit diverse activities.

In fact, experimental data showed the antihypertensive, ${ }^{13}$ antioxidative $^{\mathbf{1 4 , 1 5}}$ and anti-diabetic ${ }^{\mathbf{1 6}}$ properties from marine protein hydrolysates.

In a previous study, we demonstrated that LAPHs obtained from $L$. aurata proteins using a commercial, endogenous and microbial proteases, exhibited a variable extend antioxidant activities. ${ }^{15}$ In addition, the RP-HPLC analysis demonstrates that the bioactivities of LAPHs were directly related to the hydrophobic properties of peptides. However, the protective role of biopeptides from $L$. aurata against paracetamol induced liver injury has not been investigated. Hence, we proposed to scrutinize hepatoprotective effect of LAPHs against paracetamol-induced acute liver injury. In addition, the feasible molecular mechanisms underlying this hepatoprotective effect are discussed, involving antioxidant activities.

Golden grey mullet ( $L$. aurata) is one of the mullet species which is widely distributed in the Mediterranean Sea and Black Sea, Atlantic coasts from the Azores and Madeira northward to the British Isles, and the southern coasts of Norway and Sweden. ${ }^{17}$ L. aurata is relatively important in the fish catches of Tunisia, and is utilized for human consumption.

The aim of the present study was to evaluate, for the first way, the hepatoprotective potential and antioxidative effects of LAPHs in subacute toxicity induced by paracetamol overdose.

\section{Materials and methods}

\subsection{Materials}

Fresh golden grey mullet was purchased from the fish market of Sfax City, Tunisia. The samples were packed in polyethylene bags, placed in ice and transported to the research laboratory within $30 \mathrm{~min}$. After the fishes were washed with water, their viscera and the muscles were separated and rinsed with cold distilled water. The muscle of $L$. aurata was stored in sealed plastic bags at $-20{ }^{\circ} \mathrm{C}$ until it was used for protein hydrolysate production. The viscera were used immediately for the extraction of digestive enzymes.

\subsection{Enzymes}

Enzyme preparations from Bacillus subtilis A26 and Pseudomonas aeruginosa A2, crude enzyme extract from viscera of golden grey mullet, and commercial Trypsin and Esperase ${ }^{\circledR}$ were used. The protease activities were determined by the method of Kembhavi et al. ${ }^{18}$ using casein as a substrate.

\subsection{Production of L. aurata protein hydrolysates (LAPHs)}

LAPHs were produced as previously reported by Bkhairia et al. ${ }^{15}$ The protein hydrolysates obtained following treatment with the endogenous alkaline enzyme extract from the viscera of $L$. aurata, commercial enzymes (Trypsin and Esperase ${ }^{\circledR}$ ) and proteases from $B$. subtilis A26 and $P$. aeruginosa A2, were named as PH-LA, PH-TR, PH-ES, PH-A26, and PH-A2, respectively.

\subsection{Molecular weight distribution}

The molecular mass distribution of LAPHs was determined by size exclusion chromatography (SEC), using a high-performance liquid chromatography (HPLC) system. SEC analysis was performed using Agilent PL aquagel-OH MIXED-H preparativecolumn (300 mm × $25 \mathrm{~mm}$, Agilent, LC1260, USA), and elution was performed in $50 \%$ methanol at a flow rate of 1.5 $\mathrm{ml} \mathrm{min}{ }^{-1} .120 \mu \mathrm{l}$ of sample $\left(50 \mathrm{mg} \mathrm{ml}^{-1}\right)$ was injected onto the column which was previously calibrated with bovine serum albumin (66 kDa), egg albumin (44.5 kDa), pepsin (34 kDa), trypsin $(24 \mathrm{kDa})$ and casein $\mathrm{k}(19 \mathrm{kDa})$. Detection was monitored at $214 \mathrm{~nm}$.

\subsection{In vitro gastrointestinal simulated digestion}

The digestion procedure mimicking the physiological situation in the upper tract (stomach and small intestine) was adapted from a published method. ${ }^{19}$ Briefly, the LAPHs $\left(10 \mathrm{mg} \mathrm{ml}^{-1}\right.$ ) were resolved in suitable volume of phosphate buffer $(10 \mathrm{mM}$; $\mathrm{pH}$ 6.8) and incubated for $2 \mathrm{~min}$ at $37^{\circ} \mathrm{C}$. To produce an acidic condition of the simulated stomach solution, $1 \mathrm{ml}$ of $1 \mathrm{M} \mathrm{HCl}$ was added, followed by adding $5 \mathrm{ml}$ of pepsin solution (32 $\mathrm{U}$ $\mathrm{ml}^{-1}$ ) in $1 \mathrm{M} \mathrm{HCl}-\mathrm{KCl}$ buffer ( $\mathrm{pH}$ 1.5). The mixture was incubated for 1 hour at $37^{\circ} \mathrm{C}$ with continuous shaking. At the end of the post-gastric digestion, the mixture was immediately cooled down with ice bath and then an aliquot of $1 \mathrm{ml}$ was removed, frozen and taken for analysis of the five hydrolysates. Thereafter, the $\mathrm{pH}$ of the reaction mixture was adjusted to 6.8 with 
$1 \mathrm{M} \mathrm{NaHCO}_{3}$, and $1 \mathrm{ml}$ mixture of bile and pancreatic juice that contained bile extract $\left(13.5 \mathrm{mg} \mathrm{ml}^{-1}\right)$, pancreatin $\left(10 \mathrm{mg} \mathrm{ml}^{-1}\right)$, and trypsin $\left(14600 \mathrm{U} \mathrm{ml}^{-1}\right)$ in $10 \mathrm{mM}$ phosphate buffer (pH 8.2), was added to the solution. The mixture was allowed to stand for 3 hours at $37{ }^{\circ} \mathrm{C}$ to create duodenal condition. The enzymes were inactivated by heating at $90{ }^{\circ} \mathrm{C}$ for $10 \mathrm{~min}$. The antioxidant activities were tested using the $\beta$-carotene-linoleate bleaching model during the digestion after $30,60,120,180$, and $240 \mathrm{~min}$. The relative activities were measured and compared to that without any treatment (at $0 \mathrm{~min}$ ).

\subsection{Determination of protein oxidation}

To quantify protein oxidation, after treatment, protein samples were subjected to SDS-PAGE. Bovine serum albumin (BSA) was dissolved in phosphate buffer $(100 \mathrm{mM}, \mathrm{pH} 7.4)$ at a final concentration of $0.5 \mathrm{mg} \mathrm{ml}^{-1}$, and then incubated with or without LAPHs at $37^{\circ} \mathrm{C}$. After $30 \mathrm{~min}, \mathrm{Cu}^{2+} / \mathrm{H}_{2} \mathrm{O}_{2}(0.1 / 0.25 \mathrm{mM})$ were added to the mixture. Reactions were performed in a water bath at $37{ }^{\circ} \mathrm{C}$ for 1.5 hour. In these experiments, the same amount of phosphate buffer was added to the control groups. BSA samples were mixed with loading buffer and heated at $100^{\circ} \mathrm{C}$ for $10 \mathrm{~min} .20 \mu \mathrm{l}$ of the mixture solution was separated by $10 \%$ SDS-PAGE. After running for about 2 hours, gels were stained with $0.1 \%$ Coomassie brilliant blue R-250 for $30 \mathrm{~min}$. Band intensities were measured using Quantity one analysis software.

\subsection{Animals and treatment}

Male Wistar rats, weighing $180 \pm 20 \mathrm{~g}$ were obtained from the Central Pharmacy (SIPHAT, Tunisia). Animal maintenance and experimental procedures were performed in accordance with the Guidelines for Care and Use of Laboratory Animals of Tunis University and approved by the Animal Ethics Committee of National Institute of Health (1985). ${ }^{20}$ They were housed at ambient temperature $\left(22 \pm 2{ }^{\circ} \mathrm{C}\right)$ in a 12 hours light/dark cycle and a minimum relative humidity of $60 \% \pm 5 \%$. Food (SNA, Sfax, Tunisia) (Table 1) and water were available. One week after acclimatization to laboratory conditions, the rats were randomly divided into seven groups of six each and treatments were carried out over a period of 45 days.

Group 1: normal rats (NR) fed with the standard diet and water, Group 2: rats treated with $325 \mathrm{mg}$ of paracetamol/kg body weight (bw), by intraperitoneal injection, during the last five days of treatment period. This dose provoked toxicity without lethality. Groups 3, 4, 5, 6 and 7: rats received $350 \mathrm{mg} \mathrm{kg}^{-1}$ bw of PH-LA, PH-ES, PH-TR, PH-A2, and PH-A26, daily by gavage, during 45 days. They were treated intraperitoneally with paracetamol for the last five days of treatment period.

At the end of the experimental period, animals of the different groups were sacrificed by cervical decapitation to avoid stress.

Trunk blood samples were collected into EDTA tubes. Some of them were immediately used for the determination of hematological parameters. The sera samples were collected after centrifugation $\left(2200 \times \mathrm{g}, 15 \mathrm{~min}, 4^{\circ} \mathrm{C}\right)$, and the liver of each rat was carefully excised.

Some liver samples were immediately removed, rinsed in icecold physiological saline solution, fixed in $10 \%$ buffered formalin
Table 1 Composition of basic food (Society of Animals Nutrition "SNA", Sfax, Tunisia). This food consists of corn, soya, VMC (vitamins minerals compound) with the following characteristics

Nutritional properties (\%)

Moisture (maximal)

Fibers (maximal)

Proteins (minimal)

Fat (maximal)

Ash (maximal)

Carbohydrate

Calorific value $\left(\mathrm{kcal} \mathrm{kg}^{-1}\right)$

Amino acid (\%)

Methionine

Cysteine

Threonine

Tryptophan

Mineral mix (mg kg $\left.{ }^{-1}\right)$

Manganese

Fer

Cuivre

Zinc

Selenium

Cobalt

Iode

Vitamin and antioxidant $\left(\mathrm{mg} \mathrm{kg}^{-\mathbf{1}}\right)$

Vitamine A

Vitamine D3

Vitamine $\mathrm{H}$

Antioxidant (BHA-BHT)

0.2

solution and embedded in paraffin for histological studies. The other ones were homogenized in Tris-buffer-saline (pH 7.4) and then centrifuged $(3500 \times g, 20 \mathrm{~min})$ at $4{ }^{\circ} \mathrm{C}$. The supernatants were frozen and stored for further use in subsequent enzymatic assays. All samples were stored at $-80{ }^{\circ} \mathrm{C}$ until further use.

\subsection{DNA fragmentation assay in liver}

The DNA was isolated from the liver of the different groups by ZR Genomic DNATM-Tissue MidiPrep, Irvine, CA 92614, USA, according to manufacturer's instructions. The quality and quantity of DNA was evaluated spectrophotometrically at 260/ $280 \mathrm{~nm}$. DNA samples were analyzed on a standard $1 \%(\mathrm{w} / \mathrm{v})$ agarose gel containing ethidium bromide. Images of the ethidium bromide stained DNA agarose gel were acquired using UVP BIODOC-IT ${ }^{\mathrm{TM}}$ system.

\subsection{Biochemical estimations}

2.9.1. Protein quantification. Total protein was quantified according to the method developed by Lowry et al. ${ }^{21}$ using Folin's reagent, and bovine serum albumin (BSA) as a standard.

2.9.2. Malondialdehyde (MDA) content determination in the liver. MDA content in rat liver from all the groups were evaluated according to the level of lipid peroxide measured by thiobarbituric acid reactive substances (TBARS) in terms of MDA formation according to the method of Yagi. ${ }^{22}$

2.9.3. Determination of hepatic CAT, SOD, and GPx activities

2.9.3.1. Catalase (CAT). CAT activity was determined by the method of Aebi. ${ }^{23}$ The enzymatic reaction was initiated by 
adding $500 \mathrm{mM} \mathrm{H} \mathrm{H}_{2}$ to the supernatant $(20 \mu \mathrm{l})$. A decrease in absorbance due to $\mathrm{H}_{2} \mathrm{O}_{2}$ degradation was monitored spectrophotometrically at $240 \mathrm{~nm}$ for $1 \mathrm{~min}$ and CAT activity was expressed as $\mathrm{U} \mathrm{mg}^{-1}$ protein in liver.

2.9.3.2. Glutathione peroxidase (GPx). GPx activity was measured according to Flohé and Günzler. ${ }^{24}$ Glutathione (GSH) oxidation by GPx is coupled to the transformation of $5,5^{\prime}$ dithiobis-(2-nitrobenzoic acid) (DTNB) into 2-nitro-5thiobenzoate (TNB) which absorbs at $412 \mathrm{~nm}$. The enzyme activity was expressed as $\mathrm{U} \mathrm{g}^{-1}$ protein in liver.

2.9.3.3. Superoxide dismutase (SOD). SOD activity in the liver of rats from different groups, was assayed by the method of Sun et al. ${ }^{25}$ Enzymatic activity is proportional to the inhibition rate of nitroblue tetrazolium (NBT) oxidation by $\mathrm{O}_{2}{ }^{-}$anion. The developed blue color of the reaction was measured at $560 \mathrm{~nm}$. Units of SOD activity were expressed as the amount of enzyme required to inhibit the reduction of NBT by $50 \%$ and the activity was expressed as $\mathrm{U} \mathrm{mg}^{-1}$ of protein.

2.9.4. Determination of GSH level on hepatic tissues. Analysis of the level of GSH was performed according to method described by Ellman. ${ }^{26} 500 \mu \mathrm{l}$ of supernatant from hepatic tissue homogenate in phosphate buffer $(100 \mathrm{mM}, \mathrm{pH} 8.0)$ was added to $2 \mathrm{ml} 5 \%$ trichloroacetic acid. The mixture was centrifuged at 3500 $\times g$ for $10 \mathrm{~min}$. Five hundred microliters of supernatant were added to $250 \mu \mathrm{l}$ Ellman's reagent and $1.5 \mathrm{ml}$ phosphate buffer (100 mM, pH 8.0). The absorbance was measured at $412 \mathrm{~nm}$ after $10 \mathrm{~min}$. Total GSH content was expressed as $1 \mu \mathrm{g} \mathrm{mg}{ }^{-1}$ of protein.

2.9.5. Estimation of AST, ALT and LDH activities. AST, ALT and LDH activities used as biochemical markers for hepatic damage, were measured in frozen aliquots of serum by standardized enzymatic procedures using commercial kits from Biolabo (Maizy, France) on an automatic biochemistry analyzer (Vitalab Flexor E, USA).

\subsection{Hematological parameters examination}

The blood samples collected into EDTA tubes were used for the determination of hematological parameters. White blood cells (WBCs), red blood cells (RBCs), hematocrit (Ht), hemoglobin (Hb), mean corpuscular volume (MCV), and platelets count (Plt) were analyzed by an electronic automate Coulter MAXM (Beckman Coulter, Inc., Fullerton, CA).

\subsection{Histopathological examination}

After sacrificing the rats, liver tissues from the different groups of rats were fixed in formol solution for 24 hours for histological examination, and then transferred in a $10 \%$ formalin solution. The fixed tissues were embedded in paraffin and cutted in $4 \mu \mathrm{m}$ sections. Sections were then stained with hematoxylin-eosin for histological examination. The histological liver architecture of the control group was compared with that of the treated groups.

\subsection{Statistical analysis}

All data were expressed as mean \pm standard error mean (SEM). The significance of the differences between group means for the variables of interest were assessed by the one-way analysis of variance (ANOVA) followed by the Fisher test (Stat View).
Multiple mean comparisons were performed using a student test. Comparisons were done using either control rats or rats treated with paracetamol as references. The level of statistical significance was set at $p<0.01$.

\section{Results and discussion}

\subsection{Molecular weight distribution and amino acid composition of LAPHs}

Bioactive peptides are mostly obtained from the original proteins through enzymatic proteolysis. Since enzymes display various spectra of substrate specificity, different proteases were applied to L. aurata muscle proteins in order to obtain several types of protein hydrolysates containing peptides with different functional properties, molecular weights and amino acids compositions.

The focus of recent research has been on different protein hydrolysates which were prepared at the same enzyme/substrate ratio $\left(\mathrm{E} / \mathrm{S}=3 \mathrm{U} \mathrm{mg}^{-1}\right)$ and after incubation for 6 hours, PH-LA showed the highest degree of hydrolysis $(\mathrm{DH}=13.05 \%)$, followed by PH-TR $(\mathrm{DH}=12.67 \%)$, PH-ES $(\mathrm{DH}=12.5 \%)$, PH-A26 $(\mathrm{DH}=9.25 \%)$, and $\mathrm{PH}-\mathrm{A} 2(\mathrm{DH}=8.0 \%)$.

Treatment of protein with different enzymes produced a mixture of bioactive peptides with a different degree of hydrolysis (DH) which also could be responsible for the different range of antioxidant capacity. ${ }^{15}$

The molecular mass distribution of the LAPHs was carried out using HPLC-SEC analysis. The SEC spectra of the molecular weight (MW) peptides are shown in Fig. 1(A). The profiles of SEC spectra revealed the differences in the molecular mass distribution depending on the proteases used and consequently on the degree of hydrolysis (DH). Further, the elution profile of PH-TR and PH-LA gave the highest intensities for the last eluting peptides, characterized by their low MW. This result is in accordance with the high $\mathrm{DH}$ obtained for this hydrolysate. Indeed, more the $\mathrm{DH}$ value increased more the low MW peptides $(<10$ $\mathrm{kDa}$ ) content increased. As shown in Table 2, the levels of peptides below 3 kDa obtained in PH-LA, PH-TR, PH-ES, PH-A26, and $\mathrm{PH}-\mathrm{A} 2$, were $34.09 \%, 29.92 \%, 37.9 \%, 22.3 \%$ and $15.18 \%$, respectively, which is in accordance with their DHs.

Protein hydrolysates obtained after proteins hydrolysis are composed of free amino acids and short chain peptides, and exhibit many advantages as nutraceuticals or functional foods because of their amino acid profile.

The amino acids composition of any food protein has a significant role in various physiological activities of the human body and affects either directly or indirectly the maintenance of good health. ${ }^{27}$ Table 3 shows the amino acid composition of the LAPHs. It is obviously shown that the LAPHs contained almost all the essential and non-essential amino acids with dominance of Glu, Gln, and Lys. Pro, Leu and Gly were also present in relatively high amounts. However, the contents of His, Met, Phe and Ser were very low, as demonstrated by our results. Eight key amino acids were observed in the hydrolysate products, namely leucine, isoleucine, valine, lysine, methionine, tyrosine and phenylalanine. These amino acids are essential daily food intakes to assure normal human growth. Furthermore, amino acid compositions may also be important to antioxidant activity. Himaya et al. ${ }^{28}$ 
(A)
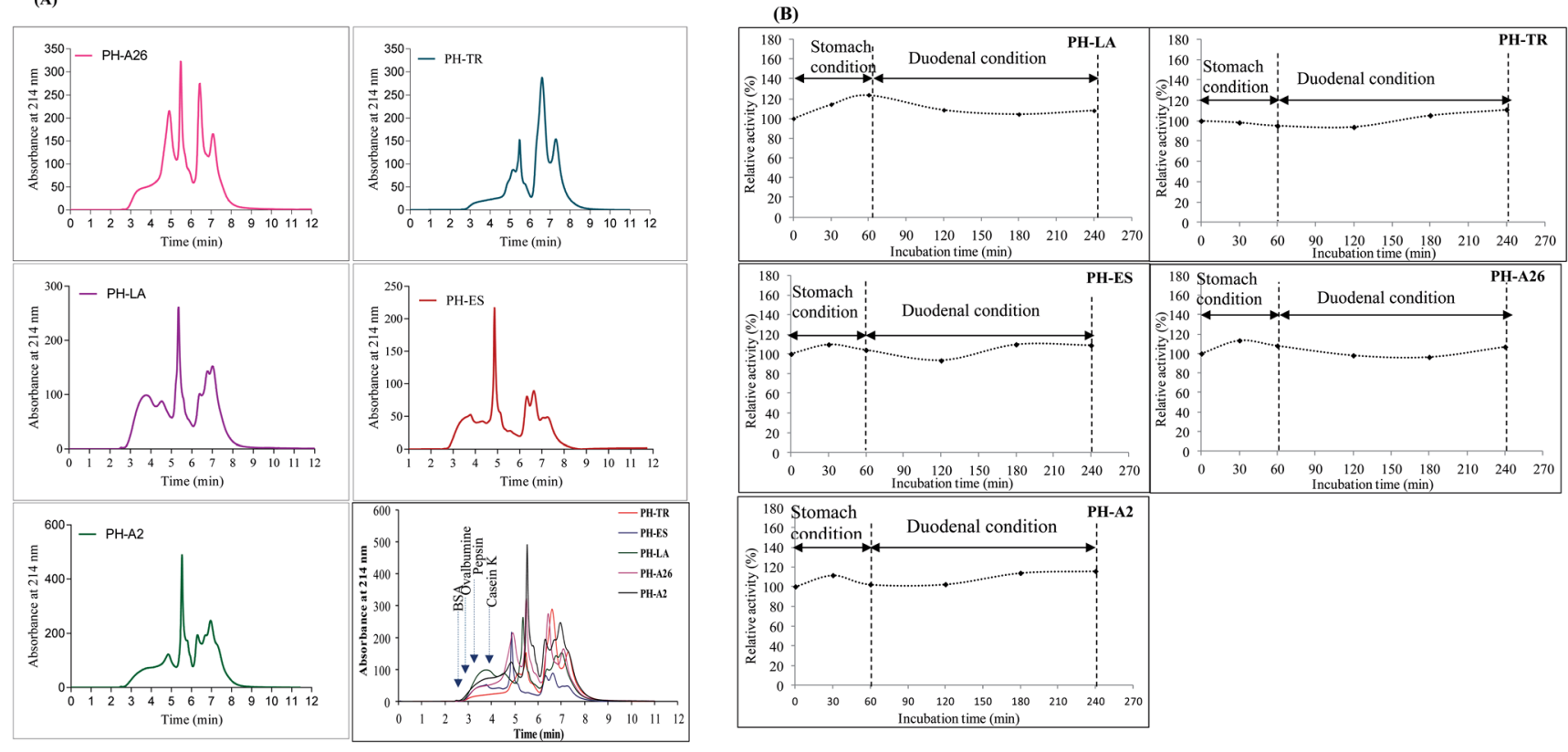

(C)

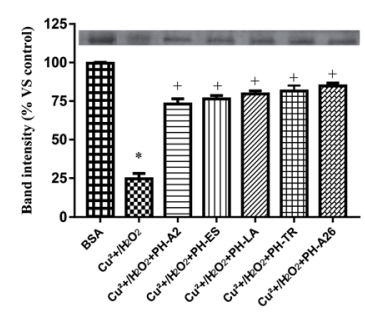

Fig. 1 In vitro study. (A) Molecular weight distribution of LAPHs by SEC chromatogram. (B) Stability of LAPHs as monitored by $\beta$-carotene bleaching assay. Values are means \pm stability of LAPHs of three determinations. (C) Protective effect of $\mathrm{LAPHs}_{\mathrm{S}}$ on $\mathrm{Cu}^{2+} / \mathrm{H}_{2} \mathrm{O}_{2}$ induced protein oxidation. BSA samples were separated by SDS-PAGE and stained with Coomassie brilliant blue R-250 (upper bands). Each value is expressed vs. control (native BSA). $\mathrm{Cu}^{2+} / \mathrm{H}_{2} \mathrm{O}_{2}$ treatment (Treat, BSA with $\mathrm{Cu}^{2+} / \mathrm{H}_{2} \mathrm{O}_{2}$ in the absence of LAPHs). ${ }^{*} p<0.01$ when the band of native BSA is compared to the band of BSA with $\mathrm{Cu}^{2+} / \mathrm{H}_{2} \mathrm{O}_{2},{ }^{+} p<0.01$ when the band of $\mathrm{BSA}$ incubated in the presence of protein hydrolysates and $\mathrm{Cu}^{2+} / \mathrm{H}_{2} \mathrm{O}_{2}$ are compared to the band of $\mathrm{BSA}+\mathrm{Cu}^{2+} / \mathrm{H}_{2} \mathrm{O}_{2}$ band.

argue that hydrophobic amino acids facilitated interactions with hydrophobic targets, such as the cell membrane, and thereby, enhanced the bioavailability. Additionally, aromatic amino acids increased the antioxidant activities of peptides and protein hydrolysates because they easily donate protons to electrondeficient radicals and maintain their stabilities via resonance structures and enhance radical scavenging activities. ${ }^{29}$ Therefore, the antioxidant activities of LAPHs could be related to the high hydrophobic and aromatic amino acid contents.

Table 2 Molecular weight distribution of LAPHs calculated from the area under curves of the profiles obtained by SEC analysis ${ }^{a}$

\section{SEC distribution}

\begin{tabular}{lllllll}
\hline Mass (kDa) & $>20$ & $20-10$ & $10-5$ & $5-3$ & $<5$ & $<3$ \\
PH-LA & 9.16 & 12.61 & 20.53 & 23.61 & 57.7 & 34.09 \\
PH-TR & 9.27 & 12.05 & 37.1 & 11.66 & 41.58 & 29.92 \\
PH-ES & 6.7 & 16.43 & 27.64 & 11.52 & 49.23 & 37.9 \\
PH-A26 & 11.13 & 18.14 & 28.67 & 19.76 & 42.06 & 22.3 \\
PH-A2 & 16.29 & 20.48 & 27.92 & 20.13 & 35.31 & 15.18
\end{tabular}

${ }^{a}$ SEC method was used to calculate the MW distribution of the LAPHs.

\subsection{Evaluation of the stability of LAPHs in gastrointestinal model system}

The oral bioactive agents administration route provides a valuable option for treating various deadly diseases because of its several advantages like cutbacks the likeliness of disease transmission, reduces medical cost and allows flexible intake schedule of administration. ${ }^{30}$ The resistance of bioactive peptides against gastrointestinal proteases, play a key role in their physiological effect in the human system and in their exploitation for human nutrition as functional foods. ${ }^{31}$ Therefore, in this study, the stability of LAPHs $\left(10 \mathrm{mg} \mathrm{ml}^{-1}\right)$, were subjected to two stages of hydrolysis that mimicking the gastrointestinal conditions. Interestingly, as shown in Fig. 1(B), the antioxidant activity, monitored by $\beta$-carotene-linoleate bleaching assay, increased slightly after pepsin and duodenal digestion, suggesting that peptides in these hydrolysates are resistant to digestion in the gastrointestinal tract. The LAPHs are resistant to gastric digestion, as is stable in the presence of acids and proteolytic enzymes, hence, it tends to remain intact during passage through the stomach. The stability of the peptides during gastrointestinal digestion promotes its specific 
Table 3 Amino acid composition (\%) of the LAPHs

\begin{tabular}{|c|c|c|c|c|c|}
\hline Amino acids & PH-A2 & PH-A26 & PH-LA & PH-TR & PH-ES \\
\hline \multicolumn{6}{|l|}{ Hydrophilic amino acid } \\
\hline Aspartic acid and asparagine (Asp and Asn) & $9.84 \pm 0.10^{\mathrm{b}}$ & $10.02 \pm 0.80^{\mathrm{a}}$ & $10.06 \pm 0.06^{\mathrm{a}}$ & $9.92 \pm 0.80^{\mathrm{a}}$ & $10.13 \pm 1.10^{\mathrm{a}}$ \\
\hline Serine (Ser) & $3.93 \pm 0.01^{\mathrm{d}}$ & $4.39 \pm 0.10^{\mathrm{a}}$ & $4.01 \pm 0.19^{c}$ & $3.83 \pm 0.21^{\mathrm{e}}$ & $4.19 \pm 0.30^{\mathrm{b}}$ \\
\hline Glycine (Gly) & $7.41 \pm 0.02^{\mathrm{d}}$ & $8.33 \pm 0.11^{\mathrm{a}}$ & $8.09 \pm 0.20^{\mathrm{b}}$ & $6.63 \pm 0.01^{\mathrm{e}}$ & $7.95 \pm 0.42^{\mathrm{c}}$ \\
\hline Histidine $^{a}$ (His) & $2.04 \pm 0.02^{\mathrm{c}}$ & $2.15 \pm 0.12^{\mathrm{b}}$ & $2.20 \pm 0.27^{\mathrm{a}}$ & $1.84 \pm 0.02^{\mathrm{d}}$ & $2.26 \pm 0.61^{\mathrm{a}}$ \\
\hline Tyrosine (Tyr) & $2.48 \pm 0.52^{\mathrm{b}}$ & $2.42 \pm 0.15^{\mathrm{b}}$ & $2.60 \pm 0.39^{\mathrm{a}}$ & $2.40 \pm 0.02^{\mathrm{b}}$ & $2.63 \pm 0.95^{\mathrm{a}}$ \\
\hline Lysine $^{a}$ (Lys) & $11.09 \pm 0.03^{\mathrm{b}}$ & $8.02 \pm 0.16^{\mathrm{e}}$ & $10.45 \pm 0.43^{\mathrm{c}}$ & $16.67 \pm 1.23^{\mathrm{a}}$ & $8.91 \pm 0.10^{\mathrm{d}}$ \\
\hline \multicolumn{6}{|l|}{ Hydrophobic amino acid } \\
\hline Proline (Pro) & $8.81 \pm 0.00^{\mathrm{b}}$ & $8.73 \pm 0.17^{\mathrm{c}}$ & $8.26 \pm 0.47^{\mathrm{d}}$ & $8.27 \pm 0.10^{\mathrm{d}}$ & $8.94 \pm 0.14^{\mathrm{a}}$ \\
\hline Alanine (Ala) & $7.04 \pm 0.00^{\mathrm{b}}$ & $7.02 \pm 0.17^{\mathrm{b}}$ & $7.08 \pm 0.51^{\mathrm{b}}$ & $6.41 \pm 0.10^{\mathrm{c}}$ & $7.87 \pm 0.00^{\mathrm{a}}$ \\
\hline Phenylalanine $^{a}$ (Phe) & $3.26 \pm 0.10^{\mathrm{b}}$ & $3.50 \pm 0.72^{\mathrm{a}}$ & $3.01 \pm 0.72^{\mathrm{c}}$ & $2.90 \pm 0.75^{\mathrm{d}}$ & $2.85 \pm 0.27^{\mathrm{d}}$ \\
\hline Total & 100 & 100 & 100 & 100 & 100 \\
\hline
\end{tabular}

${ }^{a}$ Essential amino acids. HAA: hydrophobic amino acid. Values are given as mean SD from triplicate determinations $(n=3),{ }^{\mathrm{a}, \mathrm{b}, \mathrm{c}, \mathrm{d}, \mathrm{e}}$ in the same line indicate significant differences $(p<0.01)$.

bioactivities and biological functions. Further, the slight enhancement of antioxidant activity could be explained by the release of potent bioactive peptides, from initially inactive and/or active peptides, which might enhance the protection of $\beta$-carotene from discoloration. Nasri et al. ${ }^{13}$ reported an increase in antioxidant activity of protein hydrolysates after being digested in the simulated model system. Furthermore, bioactive peptides that cannot be absorbed through the gastrointestinal tract may exert a direct role upon the intestinal lumen, or through interaction with receptors in the intestinal wall itself. Some of these receptors have been implicated in such diseases as cancer, diabetes, osteoporosis, stress, obesity, and cardiovascular complications.

\subsection{Protective effect of LAPHs on $\mathrm{Cu}^{2+} / \mathrm{H}_{2} \mathrm{O}_{2}$ induced protein oxidation in vitro}

Proteins are susceptible to damage by ROS according to previous "in vitro" 15 and "in vivo" ${ }^{26}$ studies. Their oxidation may lead to structural alterations and functional inactivation. ${ }^{32}$

Antioxidative activity of LAPHs, using protein oxidation with $\mathrm{Cu}^{2+} / \mathrm{H}_{2} \mathrm{O}_{2}$ assay, was objectified, in this study, by a decrease in the BSA degradation induced by $\mathrm{Cu}^{2+} / \mathrm{H}_{2} \mathrm{O}_{2}$. Densitometric analysis of the gel electrophoretic samples is presented in Fig. 1(C). The $\mathrm{Cu}^{2+}$ / $\mathrm{H}_{2} \mathrm{O}_{2}$ system is a metal-catalyzed system and can produce ROS and altered spectroscopic properties of albumin, increased protein carbonyl content and resulted in several conformational changes. Interestingly, LAPHs reduced significantly protein damage and protein band intensity was restored to control levels. PH-A26 (3 mg $\mathrm{ml}^{-1}$ ), was a better protector against the metal catalyzed protein oxidative damage. The incubation of BSA with PH-A26, PH-TR, PHLA, PH-ES, and PH-A2, increased significantly the band intensities by $86.20 \%, 84.0 \%, 81.0 \%, 78.0 \%$, and $75.5 \%$, respectively, compared to the BSA incubated only with $\mathrm{Cu}^{2+} / \mathrm{H}_{2} \mathrm{O}_{2}$ (Fig. 1(C)).
The inhibitory effect of LAPHs might be explained by the scavenging of hydroxyl radical generated in $\mathrm{Cu}^{2+} / \mathrm{H}_{2} \mathrm{O}_{2}$ system. The results obtained above are in agreement with our previously findings, ${ }^{15}$ with regards to the scavenging effects of LAPHs.

\subsection{Effect of LAPHs on liver DNA damage against paracetamol toxicity}

In addition to association with lipid and protein oxidation, there is clear evidence to implicate oxidative stress as a mechanism of damage in genomic DNA. The effect of paracetamol and LAPHs on the integrity of liver genomic DNA from treated rats was studied by DNA electrophoresis.

Agarose gel electrophoresis showed undetectable DNA laddering in hepatic tissues of the control rats (Fig. 2, lane 1). However administration of paracetamol (325 mg kg-1 bw) caused DNA damage resulted in DNA shearing with DNA ladder pattern (a hallmark of necrosis) (Fig. 2(A), lane 2). According to Scott et al. ${ }^{33}$ free radical generation, following xenobiotic exposure, may lead to an extensive DNA damage giving rise to mutations and/or cell death. Oxidative stress induced by oxygen-derived radicals can produce numerous modifications in DNA including base and sugar lesions, strand breaks, DNA-protein cross-links and basefree sites. Flaks and Flaks ${ }^{34}$ reported that paracetamol overdose could increase the mutation rates through oxidative damage. DNA gel electrophoresis results supported the view that LAPHs protected liver cells from necrosis and/or apoptotic death induced by paracetamol overdose. Interestingly, LAPHs prevented DNA fragmentation as evidenced by the absence of DNA laddering patter (Fig. 2(A), lane 3-7).

The protection of the DNA could be caused by the DNA repair enzyme(s) such as OGG1, stimulated by LAPHs, which must be present in the nucleus to reduce the 8-oxo-deoxyguanosine (8oxodG) incision activity. 
(A)

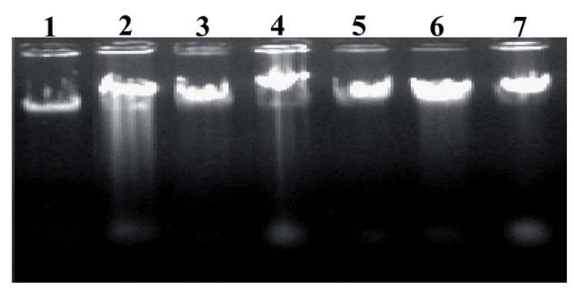

(C)

(a)

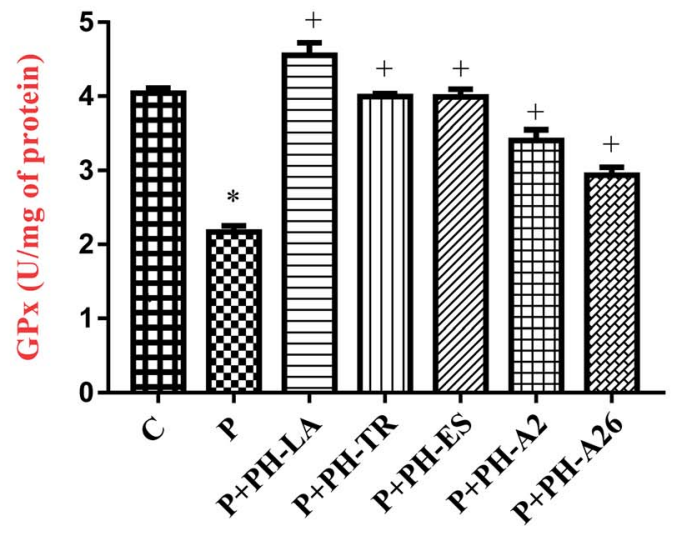

(c)

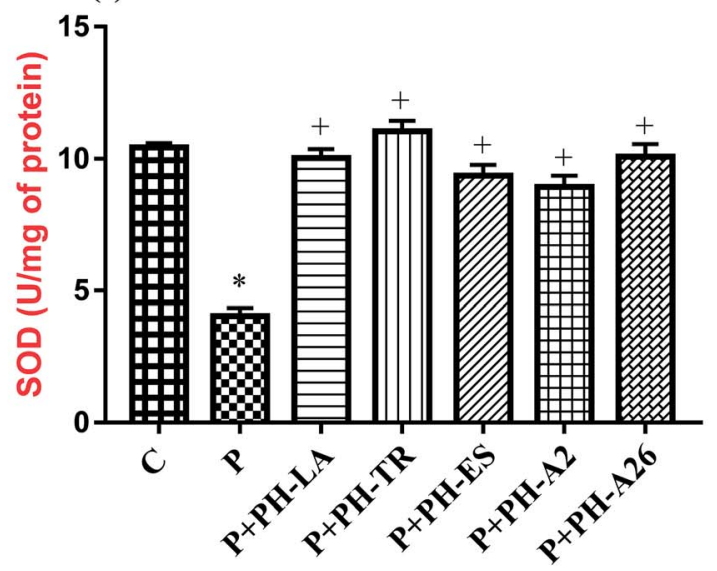

(B)

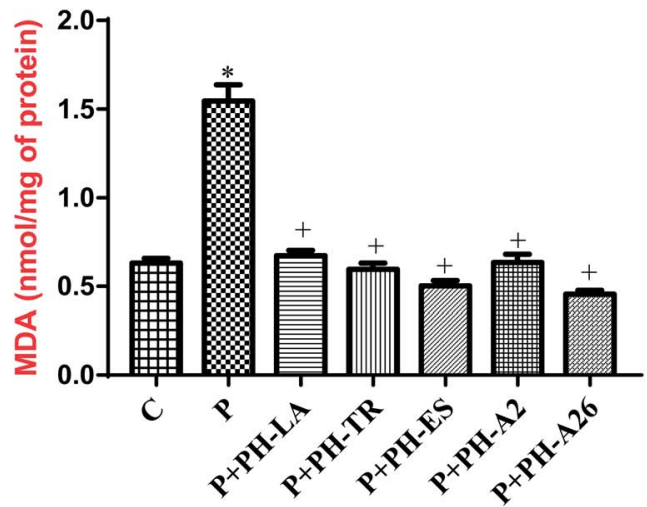

(b)

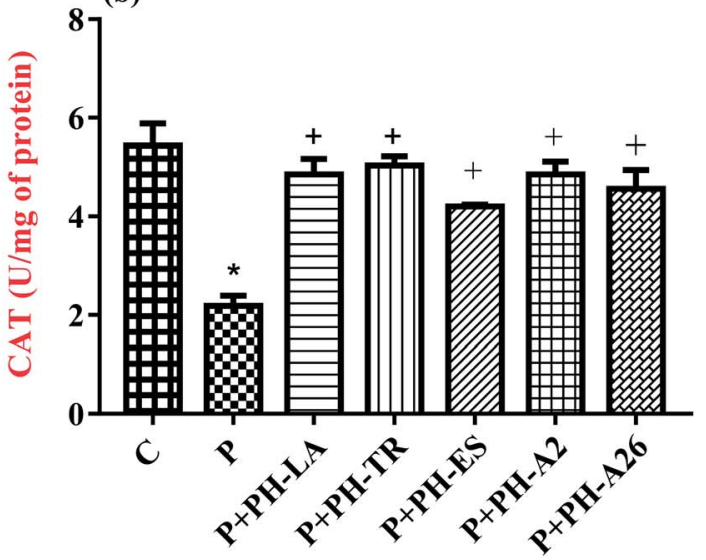

(D)

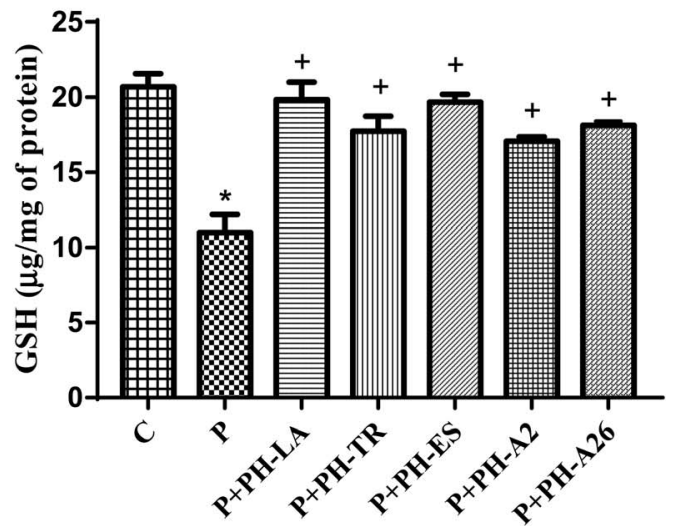

Fig. 2 In vivo study. (A) DNA fragmentation assay. Lane 1: DNA of control group. Lane 2: DNA of paracetamol treated group. Lane 3, 4, 5, 6 and 7: DNA from, PH-TR, PH-A26, PH-LA, PH-ES and PH-A2 treated rats, respectively. (B) Effect of LAPHs on liver MDA content in rats subjected to paracetamolinduced hepatotoxicity. Data are expressed as means $\pm \mathrm{SM}(n=6) .{ }^{*} p<0.01$ when the control group is compared to the paracetamol group; ${ }^{+} p<0.01$ when the treated protein hydrolysates groups are compared to the paracetamol group. (C) Effect of LAPHs on liver GPx, CAT, and SOD activities in rats subjected to paracetamol-induced hepatotoxicity. Data are expressed as means $\pm \mathrm{SM}(n=6)$. ${ }^{*} p<0.01$ when the control group is compared to the paracetamol group; ${ }^{+} p<0.01$ when the treated protein hydrolysates groups are compared to the paracetamol group. (D) Effect of LAPHs on liver GSH content in rats subjected to paracetamol-induced hepatotoxicity. Data are expressed as means $\pm \operatorname{SM}(n=6)$. ${ }^{*} p<0.01$ when the control group is compared to the paracetamol group; ${ }^{+} p<0.01$ when the treated protein hydrolysates groups are compared to the paracetamol group.

\subsection{Effect of LAPHs on hepatic toxic markers}

The liver plays a major role in regulating various physiochemical functions of the body, including synthesis, secretion and metabolism of xenobiotics.
The AST, ALT and LDH activities in the serum of the paracetamol treated group increased by $37 \%, 71.5 \%$ and $55.5 \%$, respectively, compared to the control (Table 4). A significant increase in the ALP (71.8\%) was also noted in paracetamol 
Table 4 Influence of LAPHs on AST, ALT level in rat serum in a model of paracetamol induced hepatotoxicity ${ }^{a}$

\begin{tabular}{|c|c|c|c|c|c|}
\hline Groups & $\operatorname{AST}\left(\mathrm{U} \mathrm{L}^{-1}\right)$ & $\operatorname{ALT}\left(\mathrm{U} \mathrm{L}^{-1}\right)$ & Glucose $\left(\mathrm{mmol} \mathrm{L}^{-1}\right)$ & $\mathrm{LDH}\left(\mathrm{U} \mathrm{L}^{-1}\right)$ & $\operatorname{ALP}\left(\mathrm{U} \mathrm{L}^{-1}\right)$ \\
\hline Control & $196 \pm 13.3^{\mathrm{b}}$ & $88.32 \pm 3.21^{\mathrm{d}}$ & $5.41 \pm 0.39^{\mathrm{de}}$ & $1006 \pm 24^{\mathrm{ef}}$ & $341 \pm 27^{\mathrm{ef}}$ \\
\hline Paracetamol (P) & $269.15 \pm 27.32^{\mathrm{a}}$ & $151.3 \pm 6.35^{\mathrm{a}}$ & $9.45 \pm 0.41^{\mathrm{a}}$ & $1563 \pm 38^{\mathrm{a}}$ & $586 \pm 27^{\mathrm{a}}$ \\
\hline $\mathrm{PH}-\mathrm{TR} /(\mathrm{P})$ & $145.32 \pm 18.32^{\mathrm{e}}$ & $120.96 \pm 6.18^{\mathrm{b}}$ & $7.21 \pm 0.12^{\mathrm{b}}$ & $1205 \pm 21^{b c}$ & $413 \pm 15^{\mathrm{b}}$ \\
\hline PH-ES/(P) & $156.89 \pm 11.66^{\mathrm{de}}$ & $117.69 \pm 5.32^{\mathrm{b}}$ & $6.89 \pm 0.61^{\mathrm{bc}}$ & $1102 \pm 33^{\mathrm{d}}$ & $397 \pm 19^{c}$ \\
\hline $\mathrm{PH}-\mathrm{A} 2 /(\mathrm{P})$ & $166.32 \pm 14.32^{\mathrm{d}}$ & $99.64 \pm 4.62^{\mathrm{c}}$ & $5.21 \pm 0.14^{\mathrm{e}}$ & $1086 \pm 27^{\mathrm{de}}$ & $388 \pm 10^{\mathrm{cd}}$ \\
\hline
\end{tabular}

${ }^{a}$ AST, aspartate aminotransferase; ALT, alanine aminotransferase; LDH, lactate dehydrogenase; glucose; ALP, alkaline phosphatase; PH-LA, PH-TR, PH-ES, PH-A2 and PH-A26: protein hydrolysate obtained with crude enzyme from L. aurata, trypsin, esperase, Pseudomonas aeruginosa A2 and Bacillus subtilis A26 respectively. Data expressed as mean \pm SD in each group $(n=6)$. ${ }^{\mathrm{a}, \mathrm{b}, \mathrm{c}, \mathrm{d}, \mathrm{e}, \mathrm{f}}$ The means with no common superscripts differ significantly $(p<0.01)$.

treated group. Similar results were reported by Venkatachalam and Muthukrishnan..$^{35}$ An elevation in transaminases ALP and LDH activities are attributed to the liver injury. When the liver cell plasma membrane is alterated, a variety of enzymes usually located in the cytosol are relegated into blood stream. The increased production of serum enzymes in blood stream was associated with central submassive necrosis of liver which causes severe hepatic injury. ${ }^{36}$

A significant increase in the serum glucose (74.67\%) levels was also detected. Hinson et al. ${ }^{37}$ reported hyperglycemia (500 $\mathrm{mg} \mathrm{kg}^{-1} \mathrm{bw}$ ) and glycosuria in an acetaminophenoverdosed patients. The data presented in Table 4 show, compared to the paracetamol treated group, a significant decrease in all parameters cited above in all protein hydrolysates treated groups, and values obtained were similar or slightly higher than those of the normal rats $(p<0.01)$.

The findings of the present study indicated that, the PH-TR treated rats showed the highest decrease in AST activity (46\%), followed by PH-ES (41.7\%), PH-A2 (38.25\%), PH-LA (33.8\%), and $\mathrm{PH}-\mathrm{A} 26$ (26.35\%), whereas the $\mathrm{PH}-\mathrm{S}$ treated rats showed the highest decrease in ALT, LDH, and ALP activities $(41 \%, 31.25 \%$, and $38.40 \%$, respectively) $(p<0.01)$.

The significant decrease in ALT and AST activities in the LAPHs pretreated rats demonstrated their hepatoprotective effects against paracetamol damage. Similar result was reported by Galal et al. ${ }^{38}$ The possible hepatoprotective mechanisms of LAPHs may be due to preventing the process of lipid peroxidation, inhibiting the cytochrome P-450 activity and stabilizing the hepatocellular membrane.

The mechanism of hepatoprotection by protein hydrolysates generally exerts multiple effects. Although they show hepatoprotection due to antioxidant effect, there are other effects like immunomodulatory ${ }^{39}$ and anti-inflammatory. ${ }^{40}$

\subsection{Effect of LAPHs on levels of oxidative stress parameters in liver tissue}

3.6.1. Effect of LAPHs on lipid peroxidation in liver tissue. Lipid peroxidation is an important parameter to assess the oxidative damage to lipids. When the liver is damaged by some chemical toxin, hepatocytes generate a large number of free radicals, causing lipid peroxidation of the cytomembrane to produce MDA and other derivates lipid peroxidation products.
The results presented in Fig. 2(B) show that the level of MDA in liver tissue increased in the paracetamol-treated rats by $147 \%$, compared to the control group, which indicate the oxidative effect of paracetamol. Several authors have also reported an increase in lipid peroxydation following administration of high doses of paracetamol in rats. ${ }^{41}$ Increased lipid peroxidation in paracetamol group, as evidenced by the elevated level of MDA in hepatic tissues, could be expected owing to the depletion in GSH stores and reduced GPx activity.

In our study LAPHs have shown to have a protective effect against damage caused by oxidative stress which is provoked by liver toxicity induced by overdose of paracetamol. We have seen that PH-LA, PH-TR, PH-ES, PH-A2, and PH-A26 were able to reduce the concentration of hepatic MDA by $57.77 \%, 61.50 \%$, $70.20 \%, 62.75 \%$, and $70.81 \%$, respectively, compared to the paracetamol treated group. Hepatic MDA contents of PH-ES and PH-A26 were even lower than that of the control group.

The obtained results indicate that the administration of LAPHs effectively inhibited lipid peroxidation induced by paracetamol and demonstrate their beneficial effects.

3.6.2. Effect of LAPHs on the enzymatic and non enzymatic antioxidant status in liver. In vivo, a variety of enzymatic antioxidants such as CAT, SOD, and GPx provide a primary defense against free radical induced oxidative stress. Furthermore, SOD forms a crucial part of the cellular antioxidant defense mechanism. It removes superoxide $\left(\mathrm{O}^{2-}\right)$ by converting it to $\mathrm{H}_{2} \mathrm{O}_{2}$, which can be rapidly converted to water by catalase and glutathione peroxide (GPx)..$^{42}$ Measurements of these enzymes activities are an interesting tool to evaluate the effect of bioactive molecules.

The activities of antioxidant enzymes in liver of experimental rats are shown in Fig. 2(C). Our results revealed that hepatotoxicity induced by paracetamol overdose, significantly decreased the activities of SOD, GPx, and CAT by $59.5 \%, 48.8 \%$, and $59.6 \%$, respectively, as compared to the control group $(p<0.01)$. This might lead to decreased antioxidant defense and increased oxidative stress and thereby the tissue injury occurs. Similar results have been reported by Athira et al., ${ }^{43}$ paracetamol has been reported to decrease the antioxidant enzymes activities in hepatic cells.

Pretreatment with LAPHs before paracetamol administration prevented the reduction of antioxidant enzyme activities. This might reflect the antioxidant potency of LAPHs. Our results are in 
agreement with reports of other workers which demonstrated that the administration of goby and zebra blenny to rats fed high fathigh fructose diet ${ }^{44}$ or alloxan induced diabetic rats ${ }^{27}$ increased SOD, CAT and GPx activities. The increase of antioxidant enzyme activities demonstrates the existence of the antioxidant peptides with potent free radical-scavenging activities in LAPHs.

These findings were attributed to small peptides that preventing the generation of free radicals. The improvement in the expression of these antioxidant enzymes in rats treated with LAPHs suggest that this hepatic antioxidant defense is reactivated by peptides with a resulting increase in the capacity of detoxification through enhanced scavenging of reactive oxygen radicals.

The measurement of non-enzymatic antioxidant content is a great biomarker for paracetamol intoxication. As shown in Fig. 2(D), the level of GSH in hepatic tissue of the paracetamol treated group, was markedly reduced by $49 \%$ as compared to the control group $(p<0.01)$. The decrease in the concentration of GSH in paracetamol-treated group is also an indicator of oxidative damage. The excess of NAPQI first depletes the GSH level, and then covalently binds to thiol groups of intracellular proteins, thus generating reactive oxygen species (ROS) that triggers hepatocellular necrosis. ${ }^{45}$ However, the levels of GSH, in rats pretreated with different LAPHs, were significantly restored by $90.5 \%, 70.05 \%, 84.7 \%, 95.26 \%$, and $68.84 \%$, respectively after PH-LA, PH-TR, PH-ES, PH-A2, and PH-A26 treatment, compared to the paracetamol group.

In summary, the present findings demonstrate the capability of LAPHs in promoting natural defense against ROS produced by paracetamol induced hepatotoxicity.

\subsection{Effects of LAPHs on hematological parameters}

It is well known that the liver plays a major role in homeostasis, as most of the coagulation factors, anticoagulant proteins and components of the fibrinolytic system are synthesized by hepatic parenchymal cells. Additionally, the reticuloendothelial system of the liver helps to regulate coagulation factors from the circulation. Finally, because the liver is a highly vascularized organ with vital systems draining through the parenchyma, liver diseases can affect blood flow and predispose patients to significant bleeding problems. The etiology of impaired haemostasis resulting from abnormal liver function is often multifactorial and may impaired coagulation factor synthesis, synthesis of dysfunctional coagulation factors, altered clearance of activated coagulation factors, and quantitative and qualitative platelet disorders.

In fact, we obtained in the present study an increase in the platelet number after paracetamol administration (Table 5). The hematological profile of the control and treated groups are presented in Table 5. Treatment with paracetamol resulted in a significant decrease in the levels of RBC (red blood cell), $\mathrm{Hb}$ (hemoglobin) and Ht (hematocrit) suggesting an anemia installation for rats treated with paracetamol. The diminution of blood cell count is proved by the decrease of Ht level. As known, RBCs are responsible for carrying oxygen to the body' tissues thus, changes in the numbers and/or morphology of the RBCs may indicate abnormalities or some hematological conditions.

Generally, paracetamol overdose induced hematotoxicity which was marked by several abnormalities such as leukopenia, granulocytosis and neutropenia, thrombocytopenia, and pancytopenia in rats. The recorded hematotoxicity could be secondary to the deleterious effect of paracetamol on organs of hematopoiesis in the body which include liver. ${ }^{46}$

Interestingly, this study shows that the LAPHs could contain candidate bioactive peptides reversing the hematotoxic effect of paracetamol, with ensuing improvement of hematopoiesis.

\subsection{Histopathological observations}

Histology of the liver sections of control animals showed normal hepatic architecture with well-preserved cytoplasm, and visible central veins (Fig. 3(A)). Liver sections of paracetamol-intoxicated rats revealed degenerative changes that involved the sinusoidal congestion, hemorrhages, confluent necrosis and massive inflammatory cell infiltration around perivenular area (Fig. 3(B)). Necrosis of hepatocyte is the important experimental feature in the hepatotoxicity studies. The extensive cell necrosis was the development of an inflammatory response with the recruitment of neutrophils and mononuclear cells into the liver. ${ }^{47}$ The damage extended to the majority of the hepatic lobule with marked loss of its normal pattern. The intracellular mechanisms of injury due to paracetamol in hepatocytes are the formation of reactive metabolites, depletion of glutathione and alkylation of proteins, especially the mitochondrial proteins. ${ }^{48}$ These initiating events trigger mitochondrial membrane permeability transition. The breakdown of the mitochondrial membrane permeability transition precedes the plasma membrane failure with cell swelling and leakage of cell content, i.e., cell death through oncotic necrosis. ${ }^{49}$

Table 5 Influence of LAPHs on hematologic parameters in rat liver in a model of paracetamol-induced hepatotoxicity ${ }^{a}$

\begin{tabular}{|c|c|c|c|c|c|c|}
\hline Groups & $\operatorname{RBC}\left(10^{6} \mu \mathrm{l}^{-1}\right)$ & Ht (\%) & $\mathrm{Hb}\left(\mathrm{g} \mathrm{dl}^{-1}\right)$ & CMV (fentolitre) & $\operatorname{WBC}\left(10^{3} \mu \mathrm{l}^{-1}\right)$ & $\operatorname{Plt}\left(10^{3} \mathrm{~mm}^{-3}\right)$ \\
\hline Control & $8.65 \pm 0.37^{\mathrm{a}}$ & $40.7 \pm 0.86^{\mathrm{a}}$ & $13.7 \pm 0.95^{\mathrm{a}}$ & $55.1 \pm 0.85^{\mathrm{g}}$ & $10.32 \pm 0.5^{\mathrm{g}}$ & $645 \pm 22.3^{\mathrm{e}}$ \\
\hline Paracetamol (P) & $5.23 \pm 0.47^{\mathrm{e}}$ & $36.6 \pm 0.8^{\mathrm{d}}$ & $9.6 \pm 0.9^{\mathrm{e}}$ & $22.1 \pm 0.97^{\mathrm{f}}$ & $13.56 \pm 0.13^{\mathrm{a}}$ & $1234 \pm 31.6^{\mathrm{a}}$ \\
\hline $\mathrm{PH}-\mathrm{TR}\left(\mathrm{P}^{-1}\right)$ & $7.31 \pm 0.63^{c}$ & $40.5 \pm 0.35^{\mathrm{a}}$ & $10.97 \pm 0.68^{\mathrm{c}}$ & $40.1 \pm 0.69^{c}$ & $11.32 \pm 0.72^{\mathrm{d}}$ & $836 \pm 63.1^{\mathrm{f}}$ \\
\hline PH-ES $\left(\mathrm{P}^{-1}\right)$ & $8.07 \pm 0.42^{\mathrm{b}}$ & $37.6 \pm 0.97^{\mathrm{c}}$ & $12.95 \pm 0.67^{\mathrm{a}}$ & $47.32 \pm 0,37^{\mathrm{a}}$ & $10.67 \pm 0.35^{\mathrm{f}}$ & $969 \pm 38.6^{c}$ \\
\hline $\mathrm{PH}-\mathrm{A} 2 /(\mathrm{P})$ & $8.32 \pm 0.19^{\mathrm{a}}$ & $39.6 \pm 0.81^{\mathrm{ab}}$ & $10.99 \pm 0.63^{\mathrm{c}}$ & $39.6 \pm 0,77^{\mathrm{d}}$ & $12.36 \pm 0.29^{\mathrm{b}}$ & $987 \pm 55.32^{\mathrm{b}}$ \\
\hline
\end{tabular}

${ }^{a}$ RBC, red blood cell; WBC, white blood cell; Ht, hematocrit; Hb, hemoglobin; CMV, mean cell volume; Plt, platelets. Data are expressed as mean \pm $\mathrm{SD}$ in each group $(n=6)$. ${ }^{\mathrm{a}, \mathrm{b}, \mathrm{c}, \mathrm{d}, \mathrm{e}, \mathrm{f}, \mathrm{g}}$ The means with no common superscripts differ significantly $(p<0.01)$ 
However, the rat groups pre-treated with $\mathrm{PH}-\mathrm{LA}, \mathrm{PH}-\mathrm{A} 2$ and PH-A26 exhibited significant liver protection against paracetamol-induced liver damage, as indicated by the presence of normal hepatic cells and absence of necrosis (Fig. 3(C), (F) and (G)). These results suggest the protective effect of LAPHs against chemical toxicity induced in rats. It was evidenced from the histopathological observation; the ability of LAPHs to reverse the hepatic lesions. The livers of animals treated with showed marked improvement in hepatocyte architecture in different areas around the central veins and portal tracts. This finding was consistent with the levels of the enzyme markers. Sigala et $a l .{ }^{50}$ reported that the presence of mitotic cells in hepatocytes was assessed as an index of liver proliferative capacity in response to toxin-induced injury.
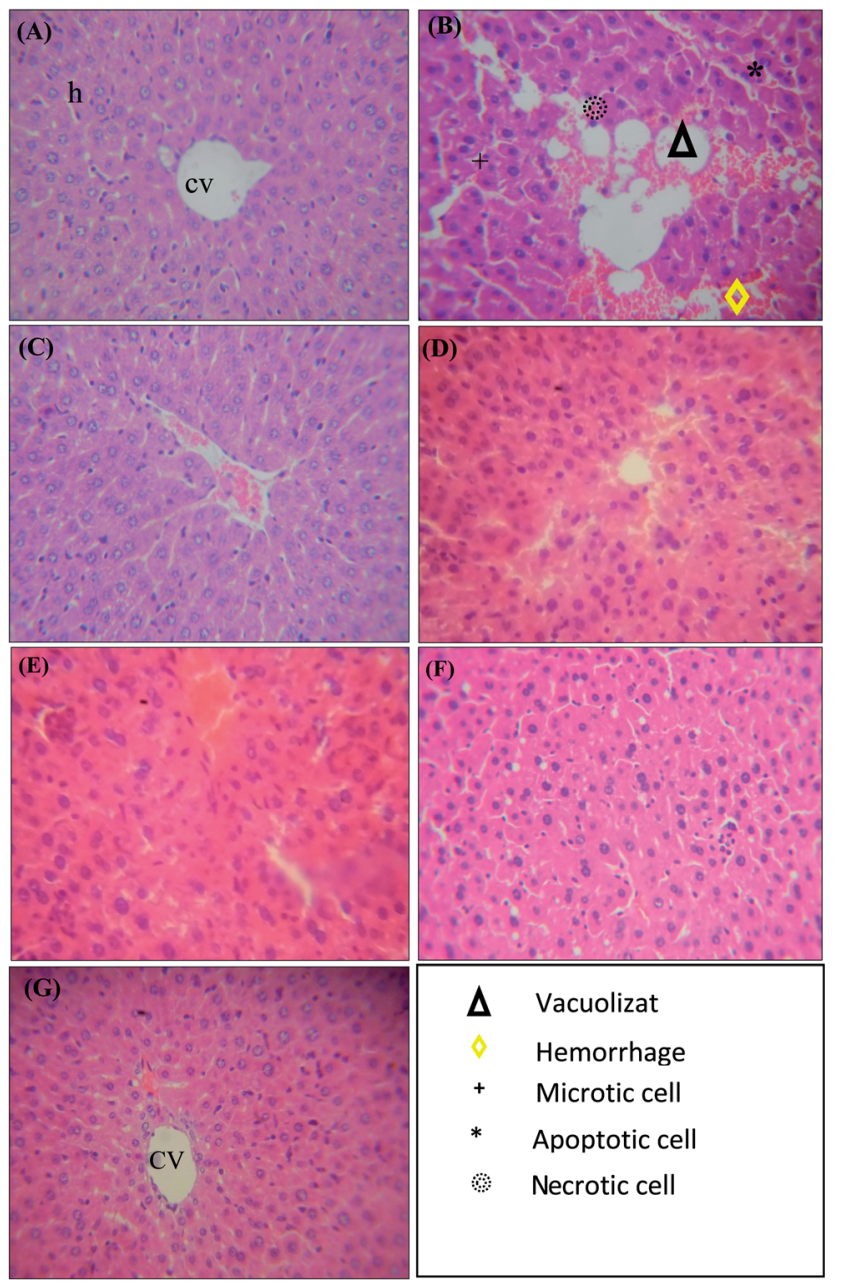

$\Delta$ Vacuolizat

Hemorrhage

$+\quad$ Microtic cell

* Apoptotic cell

: Necrotic cell

Fig. 3 Effects protein hydrolysates from Liza aurata muscle on the liver histological changes in paracetamol-induced hepatotoxicity in rats. Microscopic observations of rat liver sections (A-G: $200 \times$ ). (A) Control group showing normal hepatic architecture of the central vein (cv) and surrounding hepatocytes (h); (B) paracetamol-treated group showing cortico-inflammatory lesions, congestion and dilation of the central vein, with centrilobular necrosis in the surrounding parenchyma; (C) $\mathrm{PH}-\mathrm{A} 2 /$ paracetamol-treated group; (D) $\mathrm{PH}$-ES/paracetamol-treated group; (E) $\mathrm{PH}$-LA/paracetamol-treated group; (F) $\mathrm{PH}$ A2/paracetamol-treated group; (G) $\mathrm{PH}-\mathrm{A} 26 /$ paracetamol-treated group.

\section{Conclusion}

The present study demonstrated that pretreatment of rats with LAPHs protected the rats against paracetamol-induced hepatic damage as evidenced by a decrease in AST and ALT levels. Moreover, pretreatment with LAPHs was found to increase the antioxidant enzymes activities and GSH level as well as to decrease concentration of lipid peroxidation products. Further, liver histopathology showed that LAPHs reduced the incidence of liver lesions induced by paracetamol in rats. The obtained results suggest that protein hydrolysates from $L$. aurata contained some active peptides which possess hepato, hemato, and antioxidant potential against paracetamol-induced hepatotoxicity. Owing to its significant functionality, the incorporation of protein hydrolysates into food-based products is likely to be a promising practice for development of functional foods and nutraceuticals. Thus LAPHs may be used as a safe, cheap, and effective alternative chemopreventive and protective agent in the management of liver diseases.

\section{Ethical committee guidelines}

All animal procedures were conducted in strict conformation with the local Institute Ethical Committee Guidelines for the Care and Use of laboratory animals of our Institution.

\section{Conflicts of interest}

The authors declare that they have no competing interests to disclose.

\section{Acknowledgements}

This research was supported by the Tunisian Ministry of Higher Education and Scientific Research and the Tunisian Ministry of Public Health. The authors are grateful to Dr Khaled Dhibi, head of the surgery block of the Gafsa Hospital for his valuable encouragement and assistance in the realization of this work.

\section{References}

1 Frost and sullivan, Drug discovery and development, ed. H. P. Rang, Churchill Livingstone: Elsevier, 2007.

2 R. L. Esterline, S. D. Ray and S. Ji, Biochem. Pharmacol., 1989, 38, 2387-2390.

3 P. Nourjah, S. R. Ahmad, C. Karwoski and M. Willy, Pharmacoepidemiol. Drug Saf., 2006, 15, 398-405.

4 A. D. B. Vliegenthart, J. M. Shaffer, J. I. Clarke, L. E. J. Peeters, A. Caporali, D. N. Bateman, D. M. Wood, P. I. Dargan, D. G. Craig, J. K. Moore, A. I. Thompson, N. C. Henderson, D. J. Webb, J. Sharkey, D. J. Antoine, B. K. Park, M. A. Bailey, E. Lader, K. J. Simpson and J. W. Dear, Sci. Rep., 2015, 5, 15501.

5 J. D. Ogilvie, M. J. Rieder and R. Lim, Can. Med. Assoc. J., 2012, 184, 1492-1496.

6 S. H. L. Thomas, Toxicol. Lett., 2016, 258(suppl.), S34-S35. 
7 K. R. Atkuri, J. J. Mantovani, L. A. Herzenberg and L. A. Herzenberg, Curr. Opin. Pharmacol., 2007, 7, 355-359.

8 G. A. Mahmoudi, P. Astaraki, A. Z. Mohtashami and M. Ahadi, Int. Med. Case Rep. J., 2015, 8, 65-69.

9 H.-T. Yao, M.-N. Luo and C.-C. Li, J. Funct. Foods, 2015, 12, 262-270.

10 S. Nguyen, H. Huang, B. C. Foster, T. W. Tam, T. Xing, M. L. Smith, J. T. Arnason and H. Akhtar, J. Pharm. Pharm. Sci., 2014, 17, 254-265.

11 E. L. Andrade, A. F. Bento, J. Cavalli, S. K. Oliveira, R. C. Schwanke, J. M. Siqueira, C. S. Freitas, R. Marcon and J. B. Calixto, Braz. J. Med. Biol. Res., 2016, 49, e5646.

12 M. Nasri, in Advances in Food and Nutrition Research, Elsevier, 2017, vol. 81, pp. 109-159.

13 R. Nasri, I. Younes, M. Jridi, M. Trigui, A. Bougatef, N. Nedjar-Arroume, P. Dhulster, M. Nasri and M. KarraChâabouni, Food Res. Int., 2013, 54, 552-561.

14 R. Ben Slama-Ben Salem, I. Bkhairia, O. Abdelhedi and M. Nasri, J.Food Sci.Technol., 2017, 54, 1442-1454.

15 I. Bkhairia, R. Ben Slama Ben Salem, R. Nasri, M. Jridi, S. Ghorbel and M. Nasri, J.Food Sci.Technol., 2016, 53, 2902-2912.

16 R. Ben Slama-Ben Salem, N. Ktari, I. Bkhairia, R. Nasri, L. Mora, R. Kallel, S. Hamdi, K. Jamoussi, T. Boudaouara, A. El-Feki, F. Toldrá and M. Nasri, Food Res. Int., 2018, 106, 952-963.

17 G. Şener, A. Ö. Şehirli and G. Ayanoğlu-Dülger, J. Pineal Res., 2003, 35, 61-68.

18 A. A. Kembhavi, A. Kulkarni and A. Pant, Appl. Biochem. Biotechnol., 1992, 38, 83-92.

19 H. Enari, Y. Takahashi, M. Kawarasaki, M. Tada and K. Tatsuta, Fish. Sci., 2008, 74, 911-920.

20 National Research Council, Guide for the Care and the Use of Laboratory Animals, National Institute of Health, Bethesda, 1985, vol. 20, p. 85.

21 O. H. Lowry, N. J. Rosebrough, A. L. Farr and R. J. Randall, J. Biol. Chem., 1951, 193, 265-275.

22 K. Yagi, Biochem. Med., 1976, 15, 212-216.

23 H. Aebi, Methods Enzymol., 1984, 105, 121-126.

24 L. Flohé and W. A. Günzler, Methods Enzymol., 1984, 105, 114-121.

25 Y. Sun, L. W. Oberley and Y. Li, Clin. Chem., 1988, 34, 497500.

26 G. L. Ellman, Arch. Biochem. Biophys., 1959, 82, 70-77.

27 N. Ktari, K. Mnafgui, R. Nasri, K. Hamden, I. Bkhairia, A. B. Hadj, T. Boudaouara, A. Elfeki and M. Nasri, Food Funct., 2013, 4, 1691-1699.
28 S. W. A. Himaya, B. Ryu, D.-H. Ngo and S.-K. Kim, J. Agric. Food Chem., 2012, 60, 9112-9119.

29 N. Rajapakse, W.-K. Jung, E. Mendis, S.-H. Moon and S.-K. Kim, Life Sci., 2005, 76, 2607-2619.

30 Y. Ting, Y. Jiang, C.-T. Ho and Q. Huang, J. Funct. Foods, 2014, 7, 112-128.

31 R. Nasri, G. Chataigné, A. Bougatef, M. K. Chaâbouni, P. Dhulster, M. Nasri and N. Nedjar-Arroume, J. Proteomics, 2013, 91, 444-452.

32 M. J. Davies, S. Fu, H. Wang and R. T. Dean, Free Radicals Biol. Med., 1999, 27, 1151-1163.

33 D. Scott, S. M. Galloway, R. R. Marshall, M. Ishidate, D. Brusick, J. Ashby and B. C. Myhr, Mutat. Res., 1991, 257, 147-205.

34 A. Flaks and B. Flaks, Carcinogenesis, 1983, 4, 363-368.

35 U. Venkatachalam and S. Muthukrishnan, Biomedicine \& Preventive Nutrition, 2013, 3, 273-277.

36 P. Madhu kiran and B. Ganga Rao, International Journal of Pharmaceutical Research and Development, 2011, 3, 2.

37 J. A. Hinson, J. B. Mays and A. M. Cameron, Biochem. Pharmacol., 1983, 32, 1979-1988.

38 R. M. Galal, H. F. Zaki, M. M. Seif El-Nasr and A. M. Agha, Arch. Iran. Med., 2012, 15, 674-680.

39 Y.-S. Kim, C.-B. Ahn and J.-Y. Je, Food Chem., 2016, 202, 9-14. 40 H. Hou, Y. Fan, S. Wang, L. Si and B. Li, J. Funct. Foods, 2016, 24, 37-47.

41 A. C. B. Bandeira, T. P. da Silva, G. R. de Araujo, C. M. Araujo, R. C. da Silva, W. G. Lima, F. S. Bezerra and D. C. Costa, Chem.-Biol. Interact., 2017, 263, 7-17.

42 B. Dimitrios, Trends Food Sci. Technol., 2006, 17, 505-512.

43 S. Athira, B. Mann, R. Sharma and R. Kumar, J. Dairy Sci., 2013, 96, 1431-1437.

44 R. Nasri, O. Abdelhedi, I. Jemil, I. Daoued, K. Hamden, C. Kallel, A. Elfeki, M. Lamri-Senhadji, A. Boualga, M. Nasri and M. Karra-Châabouni, Chem.-Biol. Interact., 2015, 242, 71-80.

45 M. P. Singh, K. Y. Kim and H.-Y. Kim, Biochem. Biophys. Res. Commun., 2017, 484, 189-194.

46 O. O. Iroanya, O. A. Adebesin and J. Okpuzor, J. Clin. Diagn. Res., 2014, 8, HC15-HC21.

47 H. Jaeschke, J. Pharmacol. Exp. Ther., 1990, 255, 935-941.

48 S. D. Nelson and S. A. Bruschi, in Drug-Induced Liver Disease, Informa Healthcare, 2007, pp. 353-388.

49 K. Kon, J.-S. Kim, H. Jaeschke and J. J. Lemasters, Hepatology, 2004, 40, 1170-1179.

50 F. Sigala, S. Theocharis, K. Sigalas, S. Markantonis-Kyroudis, E. Papalabros, A. Triantafyllou, G. Kostopanagiotou and I. Andreadou, J. Pineal Res., 2006, 40, 270-279. 